\title{
Food production in solidarity economy: an issue that goes beyond laws
}

\author{
Simone WESCHENFELDER ${ }^{1,2 *}$, Bruna de OLIVEIRA ${ }^{1}$, Luiza Barth BAGATINI ${ }^{1}$, Micheli SAUERESSIG ${ }^{1}$, \\ Cecília Colling WILHELM ${ }^{1}$, André Luciano VIANA ${ }^{1}$
}

\begin{abstract}
Food production within the context of solidarity economy is an alternative way to offer employment and income for a significant part of the Brazilian population. The purpose of this study was to carry out a business diagnosis in order to evaluate the facilities, the production process and hygiene practices of seven solidarity economy enterprises located in the city of Novo Hamburgo, Southern Brazil, that work with food production and sales. Visits took place at the enterprises and a check-list was used to record data. Although food production happens in places with space and setting restrictions, it guarantees distinctive foods with aggregate value, where handlers follow the whole process, from raw materials selection to sales. Basic hygiene principles are followed, as they guarantee the production of food with quality, which contributes towards income generation for participating families. Specific laws that apply to the characteristics and needs of small-scale food production must be written in order to regulate solidarity economy enterprises.
\end{abstract}

Keywords: solidarity economy; work; food production.

Practical Application: The present study describes food production by solidarity economy enterprises and points towards the need for specific laws that apply to the characteristics of small-scale food production.

\section{Introduction}

Solidarity economy is an alternative means of work and income generation for a significant part of the Brazilian population, and it is considered the guiding principle of group work. It works with practical concepts of self-management, production and sales, all performed by the people developing the activities. The importance of sustainable consumption is relevant, as well as creating a responsible environment within a distinct market which stands out from the one that is established by big industries (Singer, 2008).

The first experiences within solidarity economy started in the 80 's, in the post-industrial period, when the first experiences with new forms of work appeared (Laville, 2009). Although solidarity economy started to build up in a more representative manner in the 90's with the creation of several co-operatives and other enterprises, room for national debate and articulation in Brazil started to take shape and materialize during the $1^{\text {st }}$ World Social Forum (Brasil, 2014) in 2001, in the city of Porto Alegre, state of Rio Grande do Sul, Brazil. In this context, four major issues were discussed: a) production of wealth and social reproduction; b) access to wealth and sustainability; c) affirmation from civil society and public spaces; d) branches of government and ethics in the new society.

Solidarity economy is defined as a means of production characterized by equality, and by equal rights, where means of production are collectively owned by the workers - this is the main characteristic (Singer, 2008). Thus, solidarity economy, buying directly from the producer, brings clients and buyers together, enabling participating in the so-called "new economy". Specifically in the Rio dos Sinos Valley, in Southern Brazil, the 1990 leather and footwear crisis triggered the creation of new work alternatives in several economic areas. In this context, working with food has become very important, as many times the preparation of a certain food that is considered a "family secret" is shared with a group of individuals, thus making it a source of work and income for this group. This different means of production has given food peculiar characteristics that cater to the needs of the consumers, as they have become scared due to the several cases of contamination of food produced in large-scale (Cruz \& Schneider, 2010).

In order to address to society demands regarding solidarity economy, incubator were created in parallel in cooperation with universities, and professionals from different areas took part in them. The main purpose was to promote advice to new enterprises, contributing towards income and work generation and promoting social inclusion (Viana, 2015).

Food production by solidarity economy enterprises has intensified since, but little is known on the facilities and processing of these foods. Thus, thinking of food and nutritional safety of both these enterprises and consumers, the objective of the presente study was to carry out a business diagnostics, analyzing the facilities, the production process and hygiene practices of solidarity economy enterprises in the city of Novo Hamburgo, Southern Brazil, that work with good production and sales. 


\section{Materials and methods}

In order to carry out this study seven incubated solidarity economy enterprises that work with food production and sales in the city of Novo Hamburgo, Southern Brazil, were selected to participate in the study. Activities started in the month of May of 2014 up until the month of December of 2014. The solidarity economy enterprises participated voluntarily in the study.

Undergraduate students and faculty from different areas who were involved with the solidarity economy incubator visited the facilities where food was processed, followed the production process. At each place na open question interview was carried out and completed a check-list that was adapted from the Brazilian Sanitary Surveillance Agency Board Resolution No. 275 from October 21, 2002 (Brasil, 2002) in order to verify the following: enterprise history, types of food that are produced and recipe origin, facilities, the group of people involved in the work, as well as environment and handlers hygiene standards throughout product production and storage.

At each enterprise that was visited the interview was answered based on answers by the person who was responsible for food production and the check list was filled out after a group analysis by the handlers, students and faculty of the nutrition program.

\section{Results and discussion}

Different reasons have led the enterprises to work with food production in solidarity economy. The economic crisis of 2000 is the most common reason. Age group, level of education and lower paying salaries within the formal market were other reasons. Even in diverse contexts, this reality demands that enterprises build collective knowledge that allow for social inclusion by creating work and income, and that are each time more important in contemporary initiatives in solidarity economy. They value possibilities of cooperative educational practices towards implementation and sustainability (Fischer, 2006).

Today, besides income generation, the enterprises highlight autonomy and freedom to determine work hours as positive aspects. Five of the participating enterprises still work informally and two are registered as individual micro entrepreneurs. When one remembers the importance of autonomy, which was highlighted by participants, it is possible to get closer to the idea that there is a certain consensus by authors that write on this topic, that the story of the people who live the achievements and challenges of solidarity economy is built by a long - and sometimes complex - process of education, of understanding the world and, mainly, by building a sense of solidarity among members. These elements foster empowerment in order to achieve tangible and intangible results (Viana, 2015).

As for the types of food that are produced, the study found cookies and crackers, chocolate truffles, brownies, cupcakes, cakes, jelly, antipasti, canapés, pizzas and pies. Enterprises reported that, whenever possible, they avoid products of animal origin due to high perishability and recommendations made by the technical team of the solidarity economy incubator and the health inspection office that follow their work.
As to recipe origin, four enterprises reported that they use recipes traditionally developed by the family and passed along generations. Three enterprises reported using the Internet and books to choose their recipes. In both cases, the enterprises report giving special touches to the recipes and that consumer reaction also influences composition and presentation. Enterprises also report that they do not use chemical additives in their recipes, since they work with materials that present a short period of expiration, and aim at preserving the health of consumers. They prefer products that are "homemade" or "artisanal food".

The food that is produced is sold weekly at solidarity economy markets that take place in the city and at outside events. The organization of these markets takes place within the solidarity economy city forum at meetings that take place monthly. These meetings foster self-management for the enterprises inside the social movement. The municipality and the solidarity economy incubator also assist the enterprises and participate in the forum meetings (Viana, 2015).

All enterprises produce food at home. Four enterprises have a specific area (home annex) and three enterprises use their home kitchen to produce food. Three out of the four enterprises that have a specific area for manipulation, as well as two of the enterprises that use the kitchen in their own homes, face difficulties related to physical space, since production areas are small and not well ventilated. This makes production more difficult during the months of intense heat and promote the entry of vectors since the doors have to remain open and they do not have proper screening. According to these enterprises, building or expanding production spaces must be long term project due to the high investment that is needed and also due to the volume of food that is produced.

Regarding equipment, the following common use kitchen supplies were found in all facilities, such as a fridge, freezer, microwave oven, electric oven, stove, blender and mixer. Only two enterprises have an industrial oven, dryer and scale, which are fundamental to produce food in larger scale and allow for production process standardization. It is important to highlight that standardization of food production is not a concern for these enterprises since, according to them, consumer choice is based on flavor and production expertise. Three out of the seven enterprises report that they have not bought new equipment yet due to financial issues, such as non-existing funding and financing for solidarity economy, as well as lack of physical space.

At the seven participating enterprises, 12 people (handlers) work directly or indirectly manipulating food for production. The number of workers varies according to demand. At each enterprise that was visited, regardless of the production volume, at every enterprise that was visited only the people in the family are involved and the mother is the main person responsible for food production and enterprise management. According to these women, one of the advantages of solidarity economy is that along with food production they can also take care of home chores.

As for hygiene, facilities were clean and organized even with limited space. Handlers wear hair covering and aprons, do not wear adornments and develop each step of production attention and care. They carefully chose raw materials and 
store the food that is produced, however there are no records or strict monitoring over raw materials regarding the first-in, first-out relation.

Regarding cross-contamination, handlers demonstrate knowledge of the main dangers in the production area, but they say that physical space restriction and the fact that the kitchen also used collectively by the Family make it sometimes difficult to control the process more effectively. It is interesting to note that even though they are not aware of technical terms, most individuals involved in food production demonstrated significant knowledge regarding conduct to be followed while manipulating. According to participants, this knowledge was built mainly after participating in workshops offered by the solidarity economy incubator, where students, faculty and enterprises exchanged experiences and knowledge.

However, it was possible to observe that two enterprises are still facing difficulties and/or aspects that need correction, such as proper hand washing, control of people coming in and out of the production area, pets in the area, residue disposal, and lack of piped water. These issues can be easily solved with technical help.

The study also observed that most enterprises face challenges regarding cash flow, sales control and other issues related to management, which proves the importance of incubation and consulting for solidarity economy enterprises on different areas, reinforcing the importance of multidisciplinary groups in the incubators.

As the visits took place, experiences were shared and questions were answered. It was evident that they have the knowledge (even if in an empirical form) and a concern with the final quality of the food that is produced. According to the enterprises, customer satisfaction is as important as the financial results. All enterprises were very welcoming and the research activities was extremely important for the team.

As observed, small scale food production is based on hand made methods that operate in processing scales far smaller than the ones used by large industries. Thus, laws and quality control programs do not exist, and are hardly present in this type of production (Maluf, 2007). The same reality was observed by Cruz et al. (2009) when they reported that the demands in terms of laboratory analysis and physical structure to legalize family agro-industries do not take into consideration the reality of production for these settings.

It is important to point out that even if there are no standard operating procedures, a best practices manual or even an authorization from health inspection authorities, it is possible to produce high-quality food in a context that is different from the industrial environment. It is important to point out the need for specific laws that apply to food produced by solidarity economy enterprises, respecting the reality and social context of each region, increasing market opportunities and strengthening the economy of the region.

\section{Conclusions}

Although the process of food production by solidarity economy enterprises in the city of Novo Hamburgo takes place in places with physical space restriction and location, it offers the production of different products with aggregate value. Handlers, family members, are responsible for the whole process, from selecting raw materials to selling. Basic hygiene principles are respected and guarantee production of high quality food, contributing towards income generation for participating families. The results found in the study will contribute towards development of initiatives aimed at the enterprises in order to help guarantee food and nutritional safety.

\section{Acknowledgements}

The authors wish to acknowledge all the solidarity economy enterprises in the city of Novo Hamburgo that produce and sell food, as well as FINEP (Research and Project Financing) and the National Program for University Incubators (PRONINC).

\section{References}

Brasil. Ministério da Saúde. Agência Nacional de Vigilância Sanitária. (2002, November 6). Regulamento técnico de procedimentos operacionais padronizados aplicados aos estabelecimentos produtores/industrializadores de alimentos e a lista de verificação das boas práticas de fabricação em estabelecimentos produtores/ industrializadores de alimentos (Resolução RDC n² 275, de 21 de outubro de 2002). Diário Oficial da República Federativa do Brasil. Retrieved from http://anvisa.gov.br/legis/resol/2002/275_02rdc.htm

Brasil. Ministério do Trabalho - MTE. (2014, November 7). Economia Solidária: histórico. Brasília. Retrieved from http://portal.mte.gov. br/ecosolidaria/historico.htm

Cruz, F. T., \& Schneider, S. (2010). Qualidade dos alimentos, escalas de produção e valorização de produtos tradicionais. Revista Brasileira de Agroecologia, 5(2), 22-38.

Cruz, F. T., Weschenfelder, S., \& Miguel, L. A. (2009). Análises físicoquímicas e implantação de boas práticas de fabricação em unidade piloto de beneficiamento de leite na metade sul do Rio Grande do Sul: experiências e reflexões. Revista Brasileira de Agroecologia, 4(2), 3098-3101.

Fischer, M. C. B. (2006). Produção e legitimação de saberes no e para o trabalho e educação cooperativa. Revista Educação Unisinos, 10(2), 154-158.

Laville, J. L. (2009). A economia solidária: um movimento internacional. Revista Critica de Ciencias Sociais, 84(84), 7-47. http://dx.doi. org/10.4000/rccs.381.

Maluf, R. S. J. (2007). Segurança alimentar e nutricional. Petrópolis: Vozes. $174 \mathrm{p}$.

Singer, P. I. (2008). Economia solidária. Estudos Avançados, 22(62), 289-314. http://dx.doi.org/10.1590/S0103-40142008000100020.

Viana, A. (2015). Economia Solidária e o mundo do trabalho: aprender e ensinar. Novo Hamburgo: Feevale. 144 p. 